
Address: 5 Revoliutsiina St., Kryvyi Rih, 50006, Ukraine E-mail: tschornaja@rambler.ru

\title{
THE DEVELOPMENT OF A MONITORING SYSTEM OF HIGHER EDUCATION QUALITY IN UKRAINE AND GERMANY: COMPARATIVE COMPONENT
}

\begin{abstract}
The article reveals specific features of functioning systems of higher education quality monitoring at the present stage, taking into account national traditions, historical experience and mentality of the population. The article introduces a comparative analysis of monitoring actors at national, regional and local levels in two countries. The ratio of influence of the state administration in education sphere and of the independent public organizations (agencies) on the nature and quality of monitoring procedures has been estimated. The positions polarity of Ukrainian and German universities in world rankings ("Top 50" The Times Higher Education World University Rankings (2010-2011/20142015); "Top 500" Academic Ranking of World Universities for 2010-2015) in form of statistical generalizations have been presented. A comparative analysis of approaches to assuring and monitoring the quality of higher education in Germany and Ukraine has been shown in the table. It demonstrates the conceptual and functional components of monitoring: the monitoring purpose, monitoring objects, levels and actors, public initiative, the priority of monitoring levels, the dominant principles, the general orientation and procedure for monitoring the higher education quality. The use of prospects of elements in progressive international experience as for organising the monitoring system of higher education quality to reform the national high school have been determined here. That could be especially important taking into consideration the creating of the European Higher Education Area.

Key words: monitoring system of higher education quality, University rankings, levels of monitoring, international monitoring, national monitoring, regional monitoring, local monitoring, monitoring objects, monitoring actors.

\section{INTRODUCTION}

The actual functional state of the quality monitoring system of higher education in Ukraine requires optimization. One of the ways to solve the problem is to use the experience of other states. A comprehensive analysis of a conceptually determined by the article theme phenomena using the tools of comparative pedagogy on the level of original research so far has not been conducted. The comparative analysis of the actual state of monitoring systems of higher education quality in Germany and Ukraine could be useful to reveal the conceptual and functional components of the monitoring such as: the monitoring purpose, monitoring objects, levels and actors, public initiative, the priority of monitoring levels, the dominant principles, the general orientation and procedure for monitoring the higher education quality.
\end{abstract}




\section{THE AIM OF THE STUDY}

The aim of the paper is a comparative analysis of the quality monitoring system of higher education in two countries participating in the Bologna process and a definition of prospects of using elements of Germany progressive experience in the reform of higher school of Ukraine.

\section{THEORETICAL FRAMEWORK AND RESEARCH METHODS}

There are lots of scientific researches of Ukrainian and German scientists who reveal the content of some elements of the analyzed concept. In some studies, the authors carry out a holistic analysis of integrated categorical formation "the quality monitoring of higher education" (I. Babin, Yu. Bobalo, H. Krasylnykova, V. Pavlysh, Yu. Romanenko, S. Shevchenko, A. Zagorodnii etc).

As methods of study were used a comparative historical analysis of the processes and phenomena of educational environment and a theoretical generalization with formulation of conclusions and recommendations on the use of German experience to improve the monitoring system of higher education quality in Ukraine.

\section{RESULTS}

The problem of efficiency (in economic terms) and quality (in social, moral, ethical, axiological and economic terms at ones) is really permanent and accompanies the higher education system from its inception. At Classic German universities of the XVI-XVIII centuries it was solved by the University community assuring the compliance of student performance indicators with requirements of the statutes that regulated curriculum, settled the order of subjects studying, fixed the procedure of awarding scientific degrees, determined periods of study and exams, the training quality requirements and other components of the educational process. Subsequently, this freedom (libertas statuendi) was greatly limited by the state, which gradually took over the function of the graduates' qualification certification (Müller, 1996).

According to Explanatory dictionary of German (DUDEN) quality is the totality of characteristic (including good, positive) properties of subject, personality, performance results ([gute] Qualität). Referring the concept of "Total Quality Management" (TQM) (Charantimath, 2009), O. Liashenko interprets the quality as a balanced compliance of process, result and educational system to the goals, needs and social norms (standards) of education (Ляшенко, 2004).

The concepts "monitoring" and "monitoring system" did not get a common interpretation till today both in Ukrainian and German sources. However, their essence is understood in the same way.

The word "monitoring" has English origin and it is usually translated into Ukrainian as "observation" or "control". In this sense, one could talk about its actual rather than terminological existence yet referring to the University of Heidelberg (1385) and the Berlin University (1810) named after Humboldt now.

In numerous documents supporting the Bologna process, in the materials of the European Association for Quality Assurance in Higher Education founded in 2000 as an Advisory member of the Bologna reform the monitoring is constantly seen as a tool of ensuring the effective functioning of the higher school (ENQA, 2006). This fact has been recognized by Ukraine and Germany as by the countries which had signed the Declaration.

The objects being monitored in Germany and Ukraine are numerous higher education institutions of different types, levels, and forms of ownership. Monitoring actors are institutions and structures of education administration and independent public 
organizations (agencies). Their role and impact on the nature and quality of the monitoring procedures in two countries differ significantly.

The important point is to define levels at which the quality assurance system of higher education should be created: international, national, institutional (Красильникова, 2014).

In the current conditions of globalizing labour market and economy tasks of a higher school as an institution for qualified human resources training are to consolidate the efforts of the actors of European Higher Education Area to assure the compliance of its activities results with generally accepted quality standards. The effective mechanism of practical solutions to this problem is an international monitoring.

The "global" level of university ratings is represented by a wide network of independent assessment agencies. "It should be emphasized that the almost all of them are focused on the evaluation of several aggregated indicators which set varies depending on the purposes and direction of rating. For example, The Academic Ranking of World Universities (ARWU) covers primary indicators that relate to the scientific activity of university teachers, in particular the number of alumni and staff winning Nobel award or Fields Medal, the number of frequently cited researchers in 21 categories, the number of articles published in Nature or Science, citation indexes for Natural Sciences and Humanities ISI, journal citation indexes, size of the university. The Times Higher Education World University Rankings cover 13 core indicators, which are grouped to five categories: teaching, international outlook, industry income, research, citations. It should be specially noted the group of ratings based on results of Internet requests, they are web metrics ratings becoming more and more popular. It is worthy of note that in conditions of rapid development of information technology, the desire of universities to improve their positions in such ratings encourages universities to be more open, transparent and mobile" (Срмошкіна, 2013). The coherence between national and international rankings, the principled adherence to the ranking principles for higher education institutions adopted at the second convocation of IREG Observatory on Academic Ranking and Excellence in Berlin (IREG, 2006), the awareness of need to implement international standards largely explain the German achievements polar to Ukrainian progress indicators summarized in Tables 1 and 2 .

At the national level, as noted by Yu. Romanenko, functions of monitoring of higher education quality (diagnostic, prognostic, managerial, organizational, informational, analytical, research, teaching, adaptation) are implemented by multilevel structure, which consists of internal (individual, local) and external monitoring.

Individual monitoring as a subsystem of a local monitoring provides for the assessment of personal achievements of each student and each teacher. Local (intra university) monitoring of education quality involves: a) self-monitoring as a selfassessment of own achievements by each student (teacher); b) pedagogical monitoring is implemented by each teacher in the current and final evaluation of educational achievements of students; c) administrative monitoring is carried out by the administration in the system of university direction and control. External monitoring of higher education quality is organized at two levels, they are regional and nationwide (Романенко, 2012). Below, we will resort to a comparison of the activity of functional structures that are engaged in the monitoring procedures at defined levels in two countries. 
Germany/Ukraine in the Times Higher Education World University Rankings (2010-2011/2014-2015) (Times, 2015)

\begin{tabular}{|c|c|c|c|c|c|c|c|c|c|c|}
\hline \multirow{2}{*}{$\begin{array}{c}\text { Category } \\
\text { of University }\end{array}$} & \multicolumn{2}{|c|}{$\begin{array}{c}2010-2011 \\
\text { Number } \\
\text { of Unis }\end{array}$} & \multicolumn{2}{|c|}{$\begin{array}{c}2011-2012 \\
\text { Number } \\
\text { of Unis }\end{array}$} & \multicolumn{2}{|c|}{$\begin{array}{c}2012-2013 \\
\text { Number } \\
\text { of Unis }\end{array}$} & \multicolumn{2}{|c|}{$\begin{array}{c}2013-2014 \\
\text { Number } \\
\text { of Unis }\end{array}$} & \multicolumn{2}{|c|}{$\begin{array}{l}2014-2015 \\
\text { Number } \\
\text { of Unis }\end{array}$} \\
\hline & 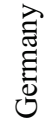 & 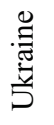 & 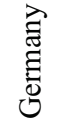 & 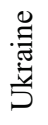 & 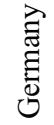 & 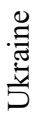 & 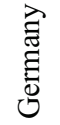 & 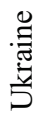 & 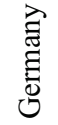 & $\begin{array}{l}\stackrel{\Xi}{\pi} \\
\frac{\pi}{5}\end{array}$ \\
\hline $\begin{array}{c}\text { 1. Top } 50 \text { Universities } \\
\text { for Arts and Humanities }\end{array}$ & 0 & 0 & 5 & 0 & 4 & 0 & 4 & 0 & 5 & 0 \\
\hline $\begin{array}{l}\text { 2. Top } 50 \text { Universities } \\
\text { for Clinical, } \\
\text { Pre-clinical and Health }\end{array}$ & 2 & 0 & 4 & 0 & 4 & 0 & 4 & 0 & 5 & 0 \\
\hline $\begin{array}{l}\text { 3. Top } 50 \text { Universities } \\
\text { for Engineering } \\
\text { and Technology }\end{array}$ & 1 & 0 & 1 & 0 & 0 & 0 & 2 & 0 & 1 & 0 \\
\hline $\begin{array}{l}\text { 4. Top } 50 \text { Universities } \\
\text { for Life Sciences }\end{array}$ & 0 & 0 & 1 & 0 & 0 & 0 & 2 & 0 & 1 & 0 \\
\hline $\begin{array}{l}\text { 5. Top } 50 \text { Universities } \\
\text { for Physical Sciences }\end{array}$ & 3 & 0 & 2 & 0 & 3 & 0 & 4 & 0 & 3 & 0 \\
\hline In total 61 Unis: & 6 & - & 13 & - & 11 & - & 16 & - & 15 & - \\
\hline
\end{tabular}

Table 2

Germany/Ukraine in the Academic Ranking of World Universities in 2010-2015 (ARWU, 2015)

\begin{tabular}{|c|c|c|c|c|c|c|c|c|c|c|}
\hline $\begin{array}{c}\text { Category of } \\
\text { University }\end{array}$ & \multicolumn{2}{c|}{$\begin{array}{c}2010 \\
\text { Number } \\
\text { of Unis }\end{array}$} & \multicolumn{2}{c|}{$\begin{array}{c}\text { Number } \\
\text { Nof Unis }\end{array}$} & \multicolumn{2}{c|}{$\begin{array}{c}2012 \\
\text { Number } \\
\text { of Unis }\end{array}$} & \multicolumn{2}{c|}{$\begin{array}{c}\text { Number } \\
\text { of Unis }\end{array}$} & \multicolumn{2}{|c|}{$\begin{array}{c}\text { Number } \\
\text { of Unis }\end{array}$} \\
\cline { 2 - 11 } & DE & UA & DE & UA & DE & UA & DE & UA & DE & UA \\
\hline $\begin{array}{c}\text { 1. Top 500 Academic } \\
\text { Ranking of World } \\
\text { Universities }\end{array}$ & 36 & 0 & 34 & 0 & 32 & 0 & 38 & 0 & 37 & 0 \\
\hline
\end{tabular}

The control and monitoring system of higher education quality in our country is in general the prerogative of Ministry of Education and Science and of several directly accountable to it specialized organizations, in particular of the State Inspectorate of Educational Institutions of Ukraine. The implementation of state educational policy is accompanied by them in full. They supervise educational institutions' accordance with the Constitution, laws of Ukraine and other regulatory legal acts in the education sphere. They carry out the planned activities of state supervision (control) in the system "... of higher education, monitor the implementation of the state standards by entities providing educational services, realize the procedures of licensing and accreditation, see to the functional compliance of higher education system and the certain institutions to requirements of international standards agreed by Ukraine and labor market needs, they do ranks of higher education institutions and monitor the training quality of pupils and students" (Президент України, 2011).

It is well known that the monitoring of higher education quality in Germany was in fact limited to local (individual, internal to university) and external (regional) levels for a long period. Even the National Accreditation Council was established in Germany at the 
federal level only in 1998, after joining the Bologna process. Prior to this event, state universities were getting accreditation certificates due to the relative simplified procedure. The accreditation of non-state universities was being carried out by the Ministries of Education of German lands in the framework of the regional legislation. The interference in the universities activity by regional administrations (Land Ministries of Education) was limited to regulation of staffing issues and coordination of the opening new specialties. However, after 1995, approaches in this matter have changed in favor of the preferring external factors of quality assuring and of the strengthening position of German Rectors' Conference. Since then, the regional system of higher education quality monitoring started to be implemented after the stepwise scheme, a bit similar to the procedure of licensing and accreditation in Ukraine. In the first stage, the university carries out a self-attestation and submits a relevant report, which contains information about the personnel, logistical, organizational and methodological support; the efficiency of learning, research, sports activities, etc. (it still reminds introspection before accreditation). The results of obligatory survey of students play the decisive role in the formulation of self-examination conclusions. The same cannot be said about the Ukrainian reality; however, the most significant differences are as follows. Next step after the studying of self-examination materials is a verification of specific educational programs (training areas) by the Attestation Commission specially created by the German Rectors' Conference in all educational institutions of the region at the same time. The conclusions about the training quality are drawn basing on the comparative analysis and are publicly available (HRK, 2012).

The actors of state monitoring (rather state control) at the regional level in the Ukraine's regions are Departments of Education and Science at regional state administrations. Among other things they have to evaluate the training quality and to assure the effective functioning of the higher education institutions network with regard to the specific characteristics and needs of the regional economy; to predict the development of higher education in the region; to determine the effectiveness of implementation of state educational reforms and international projects on the departmental territories (Дніпропетровська ОДА, 2009). However, to implement these tasks completely relative to higher education institutions of the III-IV accreditation levels is difficult because they are not under the jurisdiction of Region Departments of Education and Science.

It is advisable to compare the activity of similar in formal features structures such as the German Rectors' Conference of Land and the Rectors' Council of certain region in Ukraine at the regional level. Both collegial institutions involve rectors of certain administrative areas, but at this point their similarity is over. The Conference is given the broadest powers and full responsibility for the quality assurance of higher education in the region, the Land Ministry of Education is obliged to contribute to it.

In accordance with an item 1.4 of regulation about the Ukrainian Rectors' Council approved by order 146 of the Ministry of Education of Ukraine on the 12th of May, 1996, "decisions of Ukrainian Rectors' Council have the character of recommendations on matters within their competence". However, the item 2.7 says that "the Councils may examine the activity of individual higher education institutions on behalf of the Ministry of Education of Ukraine" (MOY, 1996), but in practice even this fiscal (but not monitoring) statement is not being realized. The Ukrainian analogue of the Rectors' Conference remains an advisory institution to the head of the regional state administration. Although in some cases at the local level the Council's task is to provide, for example, "the support and monitoring of research projects development and implementation", it does not perform any specifically determined monitoring functions in the context of higher education quality assurance (Дніпропетровська ОДА, 2013). 
Despite the importance of above characterized levels, the local (including individual), internal monitoring at German universities plays traditionally the main role in the training quality assurance. First, there are permanent acting Commissions responsible for the learning process in the structure of specialties, secondly, the effectiveness of the educational process is a point of honour, competence and responsibility for all research and teaching staff. "Currently the main trend in the field of quality assurance of higher education is shifting the center-of-gravity position from external quality control of the educational process and its results on the basis of the national system of certification and accreditation of the internal self-assessment (self-evaluation) of higher educational institutions on the basis of certain quality management models. This assures the transfer of responsibility for quality and quality assessment there, where it should be, to the higher education institution and leads to significant saving of material and labor resources devoted to conduct of external examination" (Бобало, 2014). The relevant practices are implemented in a context of strategic objectives of the Berlin Conference of Education Ministers of the countries participating in the Bologna process and the Berlin communiqué (Berlin communiqué, 2003).

It is important to note the German students' position of principle to the procedures of measuring, monitoring and evaluating results of learning and cognitive activity. Such alogisms as cheating, using someone's help during the fulfilling of individual learning tasks and other attempts to present the other's achievements as their own are not typical to their behaviour. The main difference between the Germany's monitoring system of the higher education quality and Ukrainian's one, and the advantage of former is the fact that most are interested in an objective assessment of their achievements remain the students.

An integral part of a complete monitoring system of the higher education quality must be engaging society (public organization, trade-union committees, parents, potential employers and everyone interested) to the procedure of monitoring. In Germany, the relevant aspect is taken into account, since the state monitoring policies is aimed at ensuring maximum transparency.

In Ukraine the monitoring of higher education quality is still monopolized by the state, although the need to break old stereotypes is mentioned repeatedly. "So one of the main criteria for the implementation of monitoring studies with subsequent evaluating of higher education quality by public authorities should be the extent of their sociality. ... The sociality of higher education, affiliation of state quality management of higher education to social management gives grounds to legitimize the society as an organ, with which the problematics of higher education is being created and its solutions is being directed" (Шевченко, 2013).

The comparative analysis of terminology, indicators of relatedness and differences of the process of higher education quality assuring in both countries participating in the Bologna process allows composing summary results into table 3.

Table 3

A comparative analysis of approaches to assuring and monitoring the quality of higher education in Germany and Ukraine

\begin{tabular}{|c|c|c|c|}
\hline № & Parameter/Object & Germany & Ukraine \\
\hline \multirow{3}{*}{1} & \multicolumn{3}{|c|}{ Objects of Monitoring } \\
\hline & University network & $\begin{array}{c}\text { Ramified, different types } \\
\text { of institutes of higher education }\end{array}$ & $\begin{array}{l}\text { Ramified, institutes of higher } \\
\text { education of different types and } \\
\text { accreditation level }\end{array}$ \\
\hline & Ownership of universities & State (prevail), municipal, private & State (prevail), communal, private \\
\hline
\end{tabular}




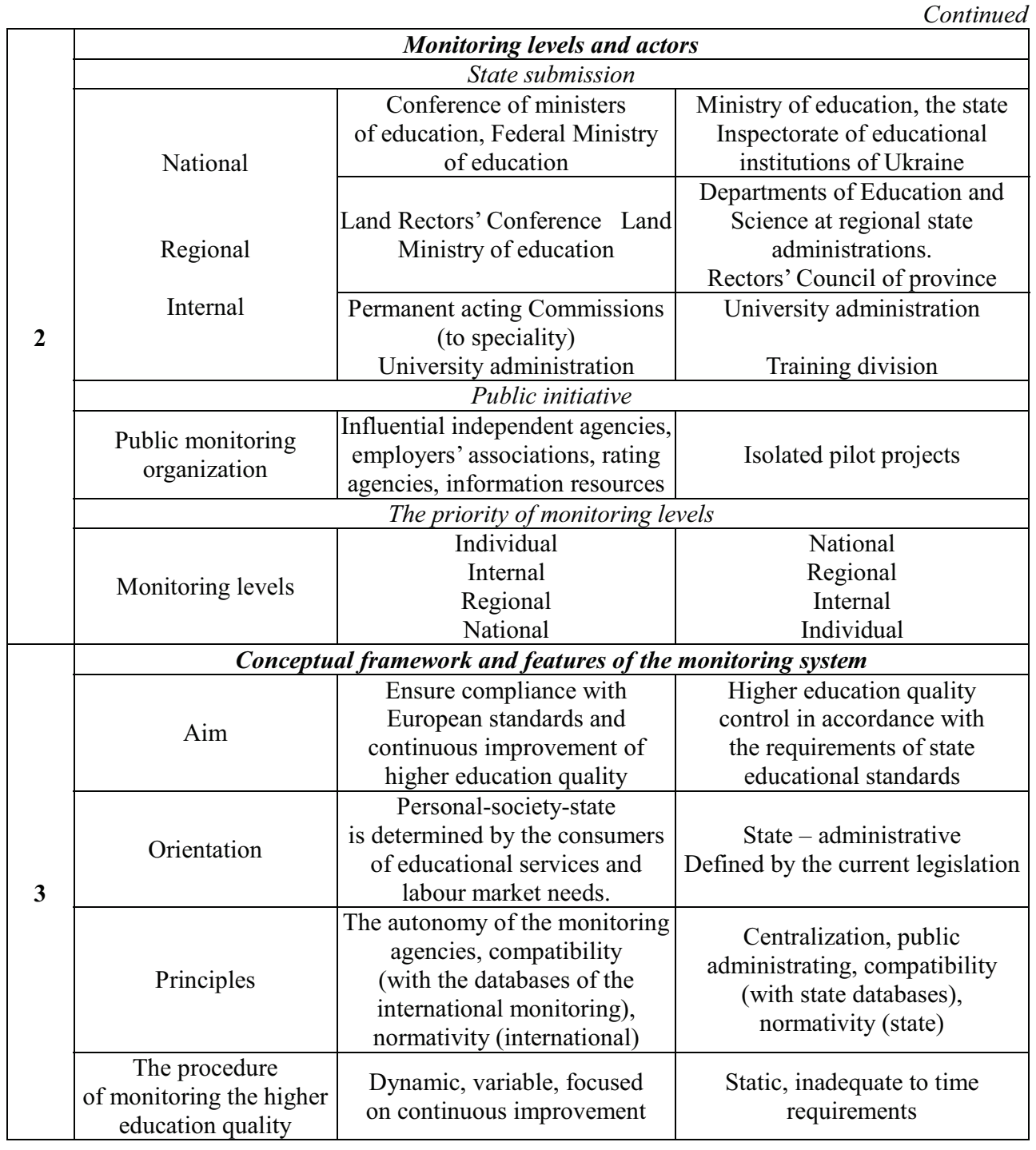

\section{CONCLUSIONS}

We have reasons to assert with certainty that the Germans soberly assessing disadvantages and accumulating advantages of separate components of the various monitoring systems of higher education quality, including French, British and American (USA), remain their own balanced and principled, so called classic German position, which has been appreciated by the whole world for a long time and placed into such a comprehensive and no opportunistic category as "German quality". Positions from 6 to 16 in the Top 50 the Times Higher Education World University Rankings and from 32 to 38 in the Top 500 Academic Ranking of World Universities in 2010-2015 are eloquent testimony of above said. As for the Ukraine, the best achievement among national universities belongs 
to the National University named after Taras Shevchenko, with its position 1283 in the World University Rankings Webometrics (Татарінов, 2013). It is hardly necessary to look for more convincing arguments in favor of the appropriateness of using Germany's experience of higher education reforming, especially when creating the National Agency for Higher Education Quality Assurance in Ukraine.

\section{REFERENCES} p. 272.

1. Charantimath, P. (2009). Total Quality Management. Delhi : Dorling Kindersley,

2. Conference of Ministers responsible for Higher Education. (2003). Realising the European Higher Education Area. Communiqué of the Conference of Ministers responsible for Higher Education in Berlin 19 September 2003. Berlin, p. 9.

3. Hochschulrektorenkonferenz. (2012). Zur Weiterentwicklung des Akkreditierungssystems: Gestaltung des Institutionellen Qualitätsaudits. In: Entschließung der Mitgliederversammlung am 24. April 2012. Retrieved 10.05.2015 from : http://www.hrk.de/positionen/gesamtliste beschluesse/position/convention/zur weiter entwicklung-des-akkreditierungssystems-gestaltung-des-institutionellen-qualitaetsaudits.

4. International Ranking Expert Group, UNESCO European Centre for Higher Education, Institute for Higher Education Policy in Washington. (2006). Berlin Principles on Ranking of Higher Education Institutions. Berlin, p. 7.

5. Müller, R. A. (1996). Student Education, Student Life. In: RidderSymoens, H., Rüegg, W. (Ed.). A History of the University in Europe: Volume II, Universities in Early Modern Europe (1500-1800). Cambridge : Cambridge University Press, p. 326-353.

6. Shanghai Ranking Consultancy. (2011). Academic Ranking of World Universities. Retrieved 01.05.2015 from : http://www.shanghairanking.com/ARWU2011.html.

7. The Times Higher Education World University Rankings. (2015). The essential elements in our world-leading formula. Retrieved 01.05 .2015 from : http://www.timeshighereducation.co.uk/world-university-rankings/2014-15/world-ranking.

8. Бобало, Ю., Павлиш, В., Загородній, А., Бабин, I. (2014). Запровадження та використання болонських інструментів прозорості в європейському просторі вищої освіти [The use and implementation of the Bologna transparency tools in European higher education area]. Вища школа [Higher school], No. 1 (115), p. 19-31 (in Ukrainian).

9. Дніпропетровська обласна державна адміністрація. (2013). Про внесення змін до Положення про раду ректорів вищих навчальних закладів при голові облдержадміністрачіï № P-439/0/3-13 [Amendments to the Statute about the Rectors' Council at the head of the regional state administration]. Retrieved 05.05.2015 from : http://search.ligazakon.ua/1_doc2.nsf/link1/DN130180.html.

10. Дніпропетровська обласна державна адміністрація. (2009). Про затвердження Положення про Головне управління освіти і науки Дніпропетровської обласної державної адміністрації N P-397/0/3-09 / [Approval of the regulations on the State Inspectorate of educational institutions of Dnipropetrovsk region]. Retrieved 05.05.2015 from : http://search.ligazakon.ua/1_doc2.nsf/link1/DN090103.html.

11. Свропейська Асоціація забезпечення якості вищої освіти (ENQA). (2006). Стандарти і рекомендації щодо забезпечення якості в Свропейському просторі вищої освіти [Standards and Guidelines for Quality Assurance in the European Higher Education Area]. Київ : Ленвіт, p. 35 (in Ukrainian). 
12. Срмошкіна, О. (2013). Забезпечення підвищення рейтингу вищих навчальних закладів в процесі інтеграції у міжнародне наукове та освітне співтовариство [Ensuring improvement of the rating of higher educational institutions in the process of integration into international scientific and educational community]. In : Proceedings of the scientific-practical conference «Удосконалення системи моніторингу забезпечення якості вищої освіти Украӥни» ["Improvement of the monitoring system of higher education quality assurance in Ukraine"]. (April 2013). Дніпропетровськ : ДВНЗ «НГУ», p. 186-191 (in Ukrainian).

13. Красильникова, Г. (2014). Європейські підходи до моніторингу якості вищої освіти [European approaches to monitoring the higher education quality]. Ocвima дорослих: теорія, досвід, перспективи [Adult education: theory, practice and perspectives], Issue 1 (8), p. 211-221 (in Ukrainian).

14. Ляшенко, О. (2004). Стратегія якості як основа освітньої політики країн світу [Quality strategy as a basis for educational policies of countries of the world]. In: Локшина, О. (Eds.). Моніторинг якості освіти: світові досягнення та украӥнські перспективи [Monitoring the education quality: global advances and Ukrainian perspectives]. Київ : К.I.С., p. 9-14 (in Ukrainian).

15. Міністерство освіти України [The Ministry of education of Ukraine]. (1996). Про затвердження Положення про ради ректорів (директорів) вищих закладів освіти України № 146 [Approval of Regulations of the Rectors’Council of higher education institutions of Ukraine]. Retrieved 05.05.20015 from : http://zakon2.rada.gov.ua/laws/show/z0294-96.

16. Президент України [President of Ukraine]. (2011). Про затвердження Положення про Державну інспекцію навчальних закладів Украӥни [Approval of the regulations on the State Inspectorate of educational institutions of Ukraine]. Київ : Офіційний вісник України, No. 29, article 1246, p. 194 (in Ukrainian).

17. Романенко, Ю. (2012). Моніторинг якості вищої освіти [The monitoring of higher education quality]. Вісник Луганського наиіонального університету імені Тараса Шевченка, №. (257), part I, p. 64-71 (in Ukrainian).

18. Татарінов, І., Герасимов, О. (2013). Світова практика формування рейтингів університетів: визначення найбільш об’єктивних критеріїв та індикаторів оцінювання [World practice of development University ratings: determining the most objective criteria and indicators to assess]. Український соиіум [Ukrainian society], Issue 1 (44), p. 100-116 (in Ukrainian).

19. Шевченко, С. (2013). Сутність, специфіка й особливості моніторингу як джерельного базису для оцінювання якості вищої освіти [The essence, peculiarities and features of monitoring as a source basis for evaluating the quality of higher education]. In : Proceeding of scientific-practical conference «Удосконалення системи моніторингу забезпечення якості вищої освіти Украӥни» ["Improvement of the monitoring system of higher education quality assurance in Ukraine"]. (April 2013). Дніпропетровськ : ДВНЗ «НГУ», p. 228-234 (in Ukrainian). 